\title{
SEJARAH SOSIAL KOTA BEKASI
}

\section{SOCIAL HISTORY OF BEKASI CITY}

\author{
Adeng \\ Balai Pelestarian Nilai Budaya Bandung \\ Jl. Cinambo 136 Ujungberung Bandung. \\ e-mail: adeng.tedja@ymail.com
}

\begin{abstract}
Abstrak
Kegiatan penelitian dan penulisan sejarah sosial baru dilakukan sekitar tahun 1950-an, baik di negara-negara maju maupun di negara-negara yang sedang berkembang. Di negara-negara yang sedang berkembang seperti Indonesia, kegiatan penelitian dan penulisan Sejarah Sosial masih sedikit dilakukan terutama yang bercorak sejarah sosial daerah. Penelitian dan penulisan sejarah yang sering dilakukan bercorak Sejarah Politik dan Sejarah Militer. Sejarah politik isinya menguraikan tentang pemerintahan kerajaan-kerajaan di Indonesia, pada masa pemerintahan Belanda, dan pendudukan Jepang. Sejarah Militer isinya tentang pertempuran-pertempuran baik melawan agresi Belanda maupun facisme Jepang. Dengan tersusunnya Sejarah Sosial Kota Bekasi diharapkan dapat diperoleh gambaran atau potret seluruh aspek kehidupan sosial daerah Kota Bekasi pada masa kini, dengan latar belakang masa lampau untuk memberikan proyeksi pada masa yang akan datang. Untuk merekontruksi digunakan metode sejarah yang meliputi empat tahap, yaitu: heuristik, kritik, interpretasi, dan historiografi. Kota Bekasi sebelumnya sebuah kecamatan dari Kabupaten Bekasi. Pada tahun 1982 Kecamatan Bekasi ditingkatkan statusnya menjadi kota administrasi. Pada tahun 1996 kembali ditingkatkan statusnya menjadi kotamadya. Dalam perkembangannya Kota Bekasi menjadi kawasan industri dan kawasan tempat tinggal kaum urban. Kota yang berada dalam lingkungan megapolitan ini merupakan salah satu kota besar urutan keempat di Indonesia yang terdapat di Provinsi Jawa Barat.
\end{abstract}

Kata kunci: Bekasi, sosial, budaya.

\begin{abstract}
The Research and writing of the new social history made around the 1950s, both in developed countries and in emerging countries. In countries like Indonesia as one of the emerging countries, research and writing of Social History is few, especially about the history of social region. Research and writing of history is often done patterned with Political History or Military History. The contents of Political history usually outlining with the era of kingdoms, and the governments in Indonesia at the time of Dutch and Japanese occupation. The contents of Military History usually discussed the battles either against the aggression of the Dutch and Japanese fascism. With the completion of the Social History of Bekasi City, hopefully it can get a photograph all aspects of the social life of the city of at present, with a background in the past to provide projections of future. This research used historical method which includes four phases: heuristic, criticism, interpretation, and historiography. In the past Bekasi well known as subdistrict of Bekasi District. In 1982 the sub-district of Bekasi upgraded to municipality or administration city. Bekasi become a city in 1996. In their development, Bekasi become a central of industrial area and as residence of urban society. The town is located in a megapolitan city of Jakarta, and one of the biggest cities in in the province of West Java.
\end{abstract}

Keywords: Bekasi, social, cultural. 


\section{A. PEN DAHULUAN}

Sejarah sosial ialah sejarah sekelompok manusia dengan ciri-ciri etnis tertentu yang berperan sebagai pendukung kebudayaan lokal, misalnya masyarakat Betawi di Kota Jakarta. Keadaan masyarakat di setiap daerah selalu mengalami perubahan dan pertumbuhan karena adanya proses sosialisasi, yang merupakan modal berharga dalam usaha mewujudkan upaya pembinaan persatuan dan kesatuan yang berbhineka (Lohanda et al., 1984: v).

Penelitian dan penulisan sejarah sosial daerah dapat dikatakan masih baru dalam dunia ilmu sejarah, baik di negaranegara maju dan terutama bagi negaranegara yang sedang berkembang. Di negara-negara maju, kegiatan penelitian dan penulisan sejarah sosial baru mendapat perhatian dan tempat sebagai kegiatan yang penting pada tahun 1950-an (Mamar et al., 1984: 1).

Kegiatan semacam itu mula-mula dipelopori oleh sarjana-sarjana Perancis, yakni: Lucian Febvre dan Marc BloclM Penulisan sejarah yang beraliran Annales itu pada akhirnya menjadi model bagi generasi baru penulis sejarah sosial yang semakin memperkuat kedudukannya dalam dunia penulisan sejarah. Penulisan sejarah yang beraliran Annales ini termasuk banyak pengaruh di kalangan para penulis sejarah sosial di Amerika (Mamar et al., 1984: 1).

Di negara-negara yang sedang berkembang seperti Indonesia, kegiatan penelitian dan penulisan sejarah sosial masih sedikit dilakukan terutama yang bercorak sejarah sosial daerah. Penelitian dan penulisan sejarah yang sering dilakukan bercorak Sejarah Politik dan Sejarah Militer. Sejarah Politik isinya menguraikan tentang pemerintahan kerajaan-kerajaan di Indonesia, pada masa pemerintahan Belanda dan pendudukan Jepang. Sedangkan Sejarah Militer isinya tentang pertempuran-pertempuran baik melawan agresi Belanda maupun facisme Jepang.
Dengan tersusunnya sejarah sosial Kota Bekasi maka diharapkan dapat memperoleh gambaran tentang kehidupan masyarakat tersebut seperti keadaannya pada masa kini, dengan latar belakang masa lampau untuk memberikan proyeksi pada masa datang. Adapun tujuan penulisan sejarah sosial adalah untuk meningkatkan pengetahuan tentang pertumbuhan dan perkembangan kehidupan masyarakat serta melengkapi bahan untuk penulisan Sejarah Daerah dan Sejarah Nasional. Dalam penulisan mencakup sektor lokasi, demografi, kependudukan, pemerintahan, sosial budaya, kesenian tradisional, sistem Penanggalan masyarakat Bekasi, upacara daur hidup, dan pengaruh budaya Mataram. Dengan demikian proses sosialisasi sebagai kejadian sejarah akan memberikan kesadaran terbinanya jiwa kebangsaan terutama pada generasi muda mengenai kesinambungan sejarah bangsa dalam rangka pembinaan bangsa.

\section{B. METOdE PENELITIAN}

Penelitian dan penulisan Sejarah Sosial Kota Bekasi menggunakan metode sejarah, yaitu meliputi empat tahap: heuristik, kritik, interpretasi, dan historiogarfi. Pada tahap heuristik dilakukan pengumpulan sumber, primer dan sumber sekunder. Untuk mendapatkan sumber tersebut penulis langsung terjun ke lapangan baik mendatangi dinas terkait yakni Dinas Kebudayaan dan Pariwisata Kota Bekasi, Badan Pusat Statistik Kota Bekasi, Perpustakaan Pemda Bekasi, dan lain-lain. Terhadap sumber yang telah diperoleh dilakukan kritik ekstern dan kritik intern, untuk menentukan otentisitas sumber dan kredibilats data/informasi. Selanjutnya, pada tahap interpretasi, dilakukan proses pemberian makna dan penafsiran, sehingga fakta-fakta tersebut dapat menjelaskan objek studi secara jelas dan lengkap. Proses terakhir adalah historiografi yang bertujuan untuk merangkaikan fakta-fakta tersebut menjadi kisah sejarah yang selaras. 


\section{HASIL DAN BAHASAN 1. Gambaran Umum Kota Bekasi a. Geografi}

Secara administrasi Kota

Bekasi merupakan salah satu kota yang masuk ke dalam wilayah Provinsi Jawa Barat. Kota Bekasi berada dalam lingkungan megapolitan Jabodetabek (Jakarta, Bogor, Depok, Tanggerang, dan Bekasi). Kota Bekasi berkembang menjadi tempat tinggal kaum urban dan sentra industri. Jarak antara Kota Bekasi dengan Ibukota Provinsi Jawa Barat $\pm 140 \mathrm{~km}$ dan jarak antara Kota Bekasi dengan Ibukota Jakarta $\pm 18 \mathrm{~km}$.

Kota Bekasi merupakan daerah dataran dengan kemiringan antara 0-2 \% dan ketinggian antara $11 \mathrm{~m}-81 \mathrm{~m}$ di atas permukaan laut. Secara geografis Kota Bekasi berada pada posisi 106055 Bujur Timur dan $6^{0}$ 7-6 $6^{0} 15$ Lintang Selatan (Bappeda, 2013: 1-2).

Kota Bekasi dilintasi oleh Jalan Tol Jakarta-Cikampek, dengan empat gerbang tol akses, yaitu Pondok Gede Barat, Pondok Gede Timur, Bekasi Barat, dan Bekasi Timur. Jalan tol Lingkar Luar Jakarta dengan empat gerbang tol akses yaitu Jati Warna, Jati Asih, Kalimalang, dan Bintara. Untuk mengatasi kemacetan lalu lintas yang menghubungkan Pusat Kota dengan Bekasi Utara, maka pemerintah bersama pengembang Summarecon Agung telah membangun jalan layang sepanjang $1 \mathrm{~km}$. Di samping itu pemerintah juga berencana akan membangun jalan layang Bulak Kapal di Jalan Joyomartono, Bekasi Timur.

Luas wilayah Kota Bekasi, 210,49 $\mathrm{km}^{2}$ dengan Kecamatan Mustika Jaya sebagai wilayah terluas $\left(24,73 \mathrm{~km}^{2}\right)$, Kecamatan Bekasi Timur sebagai wilayah terkecil $\left(13,49 \mathrm{~km}^{2}\right)$. Batas-batas wilayah administrasi yang mengelilingi wilayah Bekasi, adalah: sebelah utara dengan Kabupaten Bekasi, sebelah timur berbatasan dengan Kabupaten Bekasi, sebelah selatan berbatasan dengan Kabupaten Bogor, dan sebelah barat berbatasan dengan Provinsi DKI Jakarta (Bappeda, 2013: 7).

\section{b. Kependudukan}

Data kependudukan merupakan data yang bersifat dinamais dan strategis. Disebut dinamis karena jumlah penduduk terus mengalami perubahan dalam satu kurun waktu tertentu akibat mobilitas penduduk. Data penduduk juga merupakan data yang strategis karena digunakan sebagai perencanaan pembangunan suatu daearah.

Penduduk Kota Bekasi pada tahun 2003 berjumlah sebanyak 1.845 .005 orang yang terdiri dari 930.143 orang penduduk laki-laki dan 914.862 orang perempuan. Penduduk tersebut tersebar di 10 kecamatan 52 kelurahan. Namun demikian sebaran di setiap kecamatan tidak merata. Kecamatan Bekasi Utara yang luasnya 12,49 km2 relatif kecil dibandingkan dengan Kecamatan Bantargebang misalnya, mempunyai jumlah penduduk paling banyak yaitu 236.303 orang, kemudian diikuti oleh Kecamatan Pondok Gede sebesar 232.110 orang dan Kecamatan Jatisampurna mempunyai jumlah penduduk yang paling sedikit, yaitu berjumlah 103.952 orang (Nurwati, et al., 2005: 90-91).

Kepadatan penduduk Kota Bekasi selama periode tahun 2001-2003 dapat dikatakan mengalami perubahan yang cukup berarti. Pada tahun 2003 kepadatan penduduk sekitar 8.765 orang per $\mathrm{km}^{2}$, meningkat dari 8.596 orang per $\mathrm{km}^{2}$ pada tahun 2002. Dari 10 Kecamatan yang berada di wilayah Kota Bekasi ini, kecamatan yang luasnya paling sedikit tetapi tertinggi kepadatan penduduknya adalah Kecamatan Bekasi Timur yaitu mencapai 15.208 orang per $\mathrm{km}^{2}$, suatu kepadatan yang cukup tinggi hampir dua kali lipat dari kepadatan kota. Tingginya kepadatan penduduk di kecamatan ini dimungkinkan oleh letaknya yang berbatasan dengan DKI Jakarta. Sedangkan kecamatan yang terluas wilayahnya, tetapi terendah kepadatan 
penduduknya adalah Kecamatan Bantar Gebang yaitu 3.838 orang per $\mathrm{km}^{2}$ (Nurwati, et al., 2005: 104).

Selama kurun waktu 9 tahun tepatnya pada tahun 2012 penduduk Kota Bekasi berdasarkan data penduduk yang dipublikasikan oleh Dinas Kependudukan dan Catatan Sipil adalah 2.334.142 jiwa terdiri dari laki-laki sebanyak 1.189.733 jiwa dan perempuan 1.144.409 jiwa dan rasio jenis kelamin 103.96 (Bappeda, 2013: 20-21).

Jumlah penduduk ini tersebar pada 12 kecamatan. Berdasarkan publikasi yang dilakukan oleh Dinas Kependudukan dan Catatan Sipil, penyebaran tertinggi pada Kecamatan Bekasi Utara sebanyak 12.84\% (299.648 jiwa), Bekasi Barat $12.51 \%$ (292.015 Jiwa), Bekasi Timur 11,52\% (268.922 jiwa) dan terendah di Kecamatan Bantargebang sebesar 3.86\% (90.027 jiwa) (Bappeda, 2013: 21).

Secara etnografis terdapat 3 kelompok etnik yang cukup dominan di Kota Bekasi yaitu: etnik Sunda, etnik Betawi, dan Jawa-Banten. Berdasarkan pembagian wilayah budaya (cultur area) tersebut, maka di Kota Bekasi terdapat 3 tipologi kebudayaan, yaitu kebudayaan Sunda dengan sistem pertanian sawahnya, kebudayaan Betawi, dan kebudayaan Jawa-Banten dengan budaya pesisirnya. Di daerah perkotaan penduduknya lebih bersifat heterogen, namun demikian etnik Betawi nampak lebih dominan (Rosyadi et al, 2010: 28-29).

Selain itu, ada juga etnik Batak, Bali, Ambon, Padang, Cina, dan Arab. Orang Cina dan Arab kebanyakan tempat tinggalnya atau domisilinya di daerah perdagangan, yang tampil lebih menonjol di bidang perekonomian (Tideman, 1983: 84-85; Suparman, 1985: 193).

Banyaknya suku-suku bangsa lain menunjukkan adanya mobilitas penduduk yang tinggi. Perubahan tersebut terlihat dari jumlah penduduk Bekasi antara tahun 1927 hingga tahun 1940. Pada tahun 1927 jumlah penduduk Bekasi seluruhnya adalah 162.000 orang, terdiri atas 30 orang penduduk Eropa, 7500 orang penduduk Timur Asing, dan 154.470 orang penduduk pribumi. Kemudian pada tahun 1940 jumlah penduduk Bekasi bertambah menjadi 200.000 orang, berdasarkan data hasil laporan serah terima jabatan (Memoir van Overgave) Residen Batavia L.G.C.A, van der Hoek (Sopandi, 2009: 174).

\section{c. Pemerintahan}

Sebelum menguraikan mengenai pemerintahan Kota Bekasi terlebih dahulu akan dijelaskan tentang asal usul nama Bekasi yang memiliki beragam versi. Versi pertama, menurut Poerbatjaraka, seorang ahli bahasa Sansekerta dan Jawa Kuno asal mula kata Bekasi, secara filosofis, berasal dari kata Chandrabhaga. Chandra berarti bulan (dalam bahasa Jawa Kuno, sama dengan kata Sasi) dan Bhaga berarti bagian. Jadi, secara etimologis kata Chandrabhaga berarti bagian dari bulan. Kata Chandrabhaga berubah menjadi Bhagasasi yang pengucapannya sering disingkat menjadi Bhagasi. Kata Bhagasi ini dalam pelafalan bahasa Belanda seringkali ditulis Bacassie kemudian berubah menjadi Bekasi hingga kini (Rosyadi et al., 2010: 23-24).

Versi kedua, asal mula nama Bekasi berasal dari kata Chandrabhaga, nama sungai yang dibuat pada abad ke-5 Masehi oleh salah seorang Raja Tarumanagara yang bernama Rajadhiraja Yang Mulia Purnawarman. Kata Candrabhaga berasal dari dua kata, yakni Chandra yang berarti "bulan" dan Bhaga yang berarti "bahagia". Kata Chandra dalam bahasa Sanskerta sama dengan kata Sasi dalam bahasa Jawa kuno, sehingga nama Candrabhaga identik dengan kata Sasibhaga, yang apabila diterjemahkan secara terbalik menjadi Bhagasasi. Perkembangan selanjutnya sekitar abad ke18 sampai abad ke-21 pelafalan kata Bhagasasi mengalami perubahan menjadi nama Bekasi dengan tulisan Bakasie, Bekasjie, Bekasie, Bekassi, dan terakhir Bekasi (Sopandi, 2009: 1-2). 
Kota Bekasi sebelumnya merupakan sebuah kecamatan dari Kabupaten Bekasi. Pada tahun 1982 Kecamatan Bekasi ditingkatkan statusnya menjadi Kota Administrasi Bekasi. Maksud pembentukan Kotif Bekasi, salah satunya adalah agar pelayanan kepada masyarakat dapat lebih optimal dan memperpendek jalur birokrasi. Karena pesatnya perkembangan Kota Administratif Bekasi, pada tahun 1996 kembali ditingkatkan statusnya menjadi Kotamadya atau sekarang lebih dikenal dengan Kota Bekasi. Dengan pesatnya perkembangan, Kota Bekasi menjadi kawasan industri dan kawasan tempat tinggal kaum urban. Kota yang berada dalam lingkungan megapolitan ini merupakan salah satu kota besar urutan keempat di Indonesia yang terdapat di Provinsi Jawa Barat (Pemda Kota Madya Bekasi, 1999: 26)

Pada tahun 1998 Kota Bekasi membawahkan 8 kecamatan dan 50 kelurahan/desa. Adapun 8 kecamatan, yaitu: Bekasi Utara, Bekasi Timur, Bekasi Selatan, Bekasi Barat, Pondok Gede, Jatiasih, Bantargebang, Kecamatan Pembantu Jatisampurna. Jumlah desa sebanyak 50 itu hasil pemekaran dari dua kelurahan di Kecamatan Bekasi Barat (kalurahan Kali Baru) menjadi Kalurahan Kali Baru dan Kalurahan Kota Baru atau Kecamatan Bekasi Timur. (Kalurahan Durenjaya menjadi Kalurahan Duren Jaya dan Kalurahan Aren Jaya). Pada tahun 2000 Kota Bekasi menjadi 10 Kecamatan dan 55 kelurahan/desa. Pada tahun 2012 menjadi 12 kecamatan dan 56 kelurahan/desa (Sopandi, 2009: 139-140; Bappeda, 2013: 7).

\section{Kehidupan Sosial Budaya}

Manusia sepanjang hidupnya menerima warisan budaya yang diturunkan dari leluhurnya juga menikmati hasil budaya yang tercipta selama dia hidup. Komposisi mengenai hal itu tentu saja berbeda antara kelompok masyarakat yang satu dan kelompok masyarakat lainnya. Ada kelompok masyarakat yang lebih banyak melaksanakan aktivitas budaya kekinian. Dalam hal ini, hanya sebagian kecil warisan budaya leluhur yang masih dipertahankan dan dilaksanakan oleh mereka. Oleh karena itu, kehidupan mereka sehari-hari cenderung sama dengan kelompok masyarakat lain pada umumnya.

Gotong-royong atau tolong menolong dalam kehidupan masyarakat Kota Bekasi pada prinsipnya berakar pada perasaan saling membutuhkan. Koentjaraningrat (1974: 358), mengemukakan bahwa sistem tolong-menolong itu rupa-rupanya suatu teknik pengerahan tenaga yang mengenai pekerjaan yang tidak membutuhkan keahlian. Dengan demikian, jiwa gotong royong dan tolong menolong itu dapat diartikan sebagai perasaan rela membantu sesama warga masyarakat, sebagai sikap yang menyiratkan saling pengertian terhadap kebutuhan sesama warga masyarakat.

Berdasarkan uraian di atas, maka dalam gotong-royong terkandung prinsip timbal balik yang sudah merupakan kehidupan, bukan saja pada masyarakat Kota Bekasi, melainkan merupakan pola kehidupan masyarakat desa pada umumnya. Begitu pula dalam tolongmenolong mempererat hubungan sesama warga masyarakat dan memupuk solidaritas kebersamaan dalam mewujudkan kehidupan yang harmonis, misalnya menengok tetangga yang mendapatkan musibah, memberikan sumbangan baik berupa pikiran maupun materi kepada warga masyarakat yang mempunyai maksud seperti hajatan khitanan atau pernikahan.

Sebelumnya, penduduk Kota Bekasi didominasi oleh suku Sunda. Oleh karena itu, tentu saja budaya Sunda mewarnai kehidupan mereka secara keseluruhan. Dalam aktivitas kehidupan sehari-hari yang bersifat informal, mereka menggunakan bahasa Sunda sebagai bahasa pengantar, baik di dalam rumah maupun di lingkungan masyarakat. Sementara itu, dalam situasi dan lingkungan formal atau ketika berkomunikasi dengan orang di luar suku 
Sunda, mereka akan menggunakan bahasa Indonesia.

Namun seiring dengan perkembangan yang begitu pesat, proses migrasi penduduk di daerah ini cukup tinggi yang berdampak terhadap unsurunsur budaya luar yang berkembang di daerah Bekasi. Bekasi yang menjadi kota urban, terkena imbas budaya Betawi yang begitu mudah masuk dan memengaruhi nilai-nilai sosial, termasuk bahasa. Seringkali orang Bekasi dapat dikenali kesundaannya dari logat dan nada yang digunakan. Namun diksi dan kata-kata yang dipilih lebih mengarah ke bahasa Betawi. Sehingga dapat disimpulkan bahasa Bekasi adalah percampuran antara Betawi dan Sunda yang membuat bahasanya menjadi khas, unik, dan menarik.

Sebagaimana dikemukakan dalam Kamus Dialek Bekasi yang dibuat beberapa tahun lalu hendaknya dikritisi kembali peruntukannya. Demikian pula secara metodologis masih terkesan mengadopsi Kamus Dialek Betawi-Jakarta. Oleh sebab itu, dibutuhkan tahapan yang kritis dengan metode prosedural yang sistematis dalam menentukan identitas bahasa di daerah Bekasi. Secara realitas, daerah ini banyak mendapatkan pengaruh dari unsur-unsur lain di antaranya Sunda, Jawa, Bali, dan sebagainya, selain kebudayaan Betawi. Oleh sebab itu, bentuk dialek Bekasi pun khas dan sangat berbeda dengan dialek Jakarta. Walaupun kenyataannya, menurut Muhajir secara geografis bahasa Betawi berada di wilayah berbahasa Sunda, terutama di daerah pinggiran Jakarta (di antaranya daerah Bekasi). (Muhajir, 2000: 35; Sopandi et al., 2005: 194).

Dalam catatan sejarah, Gubernur VOC J.P. Coen pernah membuat kebijakan menutup Kota Jakarta dari penduduk pribumi dalam sebuah zona penyangga untuk menjaga keamanan pusat pemerintah dalam bentuk "Residentie Ommelanden van Batavia", banyak penduduk pribumi, Sunda hijrah ke daerah pinggiran Batavia
(Jakarta) diikuti penduduk asal Jawa yang mewarnai kosa kata bahasa daerah pinggiran, seperti ora 'tidak', lanang 'laki-laki' dan bocah 'anak-anak'. Hal inilah yang kemudian membedakan dialek bahasa Jakarta dengan ciri ucapnya banyak menggunakan vokal $e$ pada kosa katanya seperti ape, ade, aye, gue dan sebagainya dengan dialek bahasa pinggiran (Bekasi) yang tidak menggunakan vokal $e$ (pepet) tetapi vokal a seperti apa, saya, ada, gua. (Muhajir, 2000: 35; Sopandi et al., 2005: 194).

Selain pengaruh bahasa SundaJawa-Bali, bahasa di daerah Bekasi pun banyak mendapat pengaruh unsur-unsur bahasa Cina, terutama dalam bahasa sehari-hari masyarakat Bekasi dalam menghitung biasanya menggunakan hitungan-hitungan bahasa Cina, seperti cepek, gopek, dan sebagainya.

Menurut Stephen Wallace dalam Muhajir (2000: 70), secara umum dialek Jakarta dan pinggiran dikelompokkan dalam dua dialektal, yaitu: dialek Betawi Tengahan (DKI Jakarta) dan dialek Betawi Pinggiran (Bekasi, Bogor dan Tangerang) sejajar dengan sejarah kependudukannya. Suku Betawi yang tinggal di pertengahan kota sedangkan di wilayah pinggiran terdapat penduduk bercirikan Jawa dan Sunda, Bali, dan Sunda-Banten.

Bekasi mengalami proses asimilasi dan akulturasi kebudayaan seperti yang telah disebutkan di atas dari berbagai daerah seperti Bali, Melayu, Bugis, dan Jawa. Pengaruh etnis tersebut tersebar di wilayah Bekasi, antara lain: Suku Sunda banyak bermukim terutama di wilayah Lemahabang; Cibarusah, Setu, sebagian Pebayuran dan sebagian Pondok Gede. Suku Jawa dan Banten banyak bermukim di Kecamatan Sukatani dan sebagian Cabang Bungin. Suku bangsa Melayu banyak bermukim di Kecamatan Bekasi (daerah kota), Cilincing (sekarang masuk Jakarta), Pondok Gede, Babelan, Tambun, Cikarang, Cabang Bungin, dan Setu. Suku Bali terdapat di sebuah kampung di Kecamatan Sukatani, bahkan sampai 
sekarang namanya masih Kampung Bali. Keberadaan penduduk yang berasal dari berbagai etnis tersebut telah memengaruhi pola hidup dan bahasa ${ }^{1}$.

\section{a. Kesenian Tradisional}

Kota Bekasi secara umum juga memiliki kekayaan budaya yang tidak kalah menariknya dengan kota/kabupaten lain yang ada di Jawa Barat, di antaranya beragam kesenian tradisional yaitu: kesenian tari topeng, tanjidor, lenong, gambang kromong, wayang kulit, wayang golek, ujungan, musik gambus, dan permainan anak-anak.

Tari topeng Bekasi merupakan teater rakyat yang sudah berkembang di wilayah budaya Betawi pinggiran lebih dari setengah abad. Kesenian ini dapat dikatakan merupakan bentuk lain dari kesenian banjet di Pasundan, terutama di daerah Karawang.

Menurut asal-usulnya, sewaktu Belanda menduduki Batavia, Mataram masuk dalam sasaran Belanda untuk ditaklukkan. Sementara itu, Mataram mempunyai ambisi besar untuk menguasai Pulau Jawa. Untuk mewujudkan ambisinya itu, Batavia yang sudah diduduki Belanda diserang oleh Mataram. Namun dalam serangan itu, Mataram gagal untuk menguasai Batavia dari tangan Belanda. Kemudian para prajuritnya diperintahkan tetap berjaga-jaga di pos terdepan sambil mengadakan gerilya, mengganggu Belanda, atau menjadi mata-mata. Tidak sedikit dari para prajurit tersebut menjadi jawara, memiliki kekebalan fisik, dan mempunyai kemahiran baik dalam menggunakan senjata tajam, pencak silat, dan bela diri. Sejak saat itulah perjuangan melalui seni mulai juga dilancarkan, seni pencak silat dipakai sebagai refleksi jawara untuk menyindir kehidupan sosial Belanda, mereka juga menggunakan bentuk lawakan

${ }^{1}$ Diakses dari:

http://www.bekasiurbancity.com/blog/2013/06/

30/tari-topeng-peninggalan-seni bu-daya-

bekasi/\#sthash.Flc5iNAf.dpuf dan lelucon. Bentuk ekspresi seni melalui gerakan yang indah gemulai dipilih dalam bentuk tarian yang menggambarkan jiwa heroik dan patriotik. Kombinasi antara pencak silat, lawak, dan tarian itulah menjadi unsur seni topeng (Rosyadi et al., 2010: 39-40).

Awal mula munculnya, Tari Topeng dimainkan sebagai penghibur pada acara hajatan rakyat seperti hajat bumi atau pun mauludan. Tari Topeng tersebut ditanggap/diselenggarakan oleh para petani guna menyambut panen padi tiba, tujuannya sebagai rasa syukur kepada Dewi Sri yang dipercaya memberikan keberhasilan pertanian.

Peralatan yang digunakan dalam topeng Bekasi terdiri atas: kendang, salendro, saron, bende. Adapun kelengkapan busana yang dikenakan oleh penari wanita, adalah:

- Kembang Topeng, yaitu hiasan mahkota yang terbuat dari benang wol yang menyerupai sanggul (dengan ukuran kecil dan sedang) dihiasi dengan aneka kembang yang berwarna-warni serta rambut memakai cepol.

- Toke-toke, yaitu selempang yang dipakai di dada dengan posisi menyilang, toketoke ini dihiasi manik-manik.

- Kebaya bosrok, yaitu kain berlengan sampai sikut yang berwiru tiga susun.

- Amprok, yaitu kain bersulam yang dipakai untuk menutupi pusar yang berjubai.

- Kain sarung yaitu kain yang dipakai untuk menutupi bagian bawah badan dari pinggul sampai mata kaki.

- Selendang yang dipakai di sebelah kiri dan kanan yang diselipkan pada ikat pinggang (Rosyadi et.al., 2010: 40-41).

Sementara itu penari laki-laki mengenakan baju kemaja, celana panjang, dan topeng. Dahulu pertunjukan Topeng Bekasi biasa diselenggarakan di pelataran atau halaman rumah dengan alat penerangan obor. Sekarang kesenian ini biasa dipertunjukkan di atas panggung hiburan atau gedung pertunjukan dengan penerang listrik. Pertunjukan biasanya 
dilaksanakan pada malam hari, antara pukul 20.00 hingga 02.00 , dengan jumlah pemain antara 20 -- 25 orang termasuk penabuh.

Kesenian tanjidor adalah sebuah kesenian tradisional Betawi yang hidup di wilayah budaya Betawi pinggiran, termasuk di Kota Bekasi. Tanjidor merupakan sejenis kesenian orkes rakyat Betawi, yang menggunakan alat-alat musik Barat, terutama alat tiup terompet dan tambur atau drum band.

Kesenian ini dinamai tanjidor karena didominasi oleh suara dor-dor yang keluar dari bunyi tambur atau drum band yang cukup dominan dalam pertunjukan kesenian ini. Sebagian masyarakat Bekasi ada juga yang menyebut kesenian ini dengan nama gebret, yang diambil dari bunyi terompet, yang juga dominan dalam kesenian ini.

Kesenian tanjidor berkembang di daerah Bekasi sekitar abad ke-19. Kesenian tanjidor merupakan warisan kebudayaan dari bangsa Eropa yang menetap di Batavia (Jakarta). Oleh karena itu, alat musik yang dimainkan dalam kesenian tanjidor biasanya merupakan alat musik yang berasal dari Eropa Barat yang terdiri atas alat musik tiup dan tambur. Alat musik tiup terdiri atas piston, trombon, dan klarinet. Sedangkan alat musik tambur (dipukul) terdiri atas tenor drum, bass drum, dan snar drum. Selain alat-alat tersebut, kesenian tanjidor juga dilengkapi dengan alat musik lain yaitu biola, ringbells, dan lain-lain (Sopandi, 2009: 243).

Busana yang dikenakan adalah busana sehari-hari. Laki-laki mengenakan celana panjang, baju lengan panjang, dan memakai peci, sedangkan wanita mengenakan kain, kebaya, dan berkerudung.

Lagu-lagu yang dibawakan tanjidor adalah Batalion, Kramton, Bananas, Delsi, Was Tak-tak, Cakranegara, dan Welmes. Semua penamaan tersebut berdasar istilah setempat. Perkembangan selanjutnya dibawakan pula lagu-lagu Sunda-Gunung, seperti Kang Haji, Oncom lele, dan sebagainya (Rosyadi et.al., 2010: 32)

Kesenian tanjidor bukan hanya merupakan seni pertunjukan untuk menghibur masyarakat tetapi bisa pula dimainkan pada acara perkawinan, yaitu saat mengiringi rombongan pengantin pria menuju rumah pengantin wanita. Dewasa ini kegiatan tersebut sudah sangat jarang dilakukan. Kelompok kesenian tanjidor sendiri saat ini sudah jarang yang aktif bahkan sebagian besar sudah bubar. Selain kurangnya minat generasi muda untuk belajar dan menjadi seniman tanjidor, juga disebabkan alat-alat musik tanjidor dari kelompok-kelompok yang sudah pernah ada sudah banyak yang rusak dimakan usia. Sedangkan untuk menggantikannya dengan yang baru sulit dilakukan karena susah pembuatannya dan biayanya cukup tinggi. Di samping itu, pengaruh budaya Barat sangat besar di kalangan generasi muda, sehingga mereka tidak berminat menekuni budaya tradisional yang dianggap ketinggalan zaman (Sopandi, 2009: 243).

Lenong merupakan jenis kesenian rakyat Bekasi yang beralunan gambang kromong dan diselingi dengan bodoranbodoran atau lawakan tanpa plot cerita. Bobodoran tersebut berisi kritik sosial terhadap penguasa, atau masyarakat yang tidak mau berkembang. Pada intinya lenong menampilkan cerita tentang kehidupan sehari-hari para jagoan, tuan tanah, drama rumah tangga, dan lain-lain. Lenong adalah bentukan dari teater peran, yang merupakan hasil perkembangan teaterisasi teater tutur gambang rancag. Secara visual, lenong menunjukkan unsurunsur pengaruh dari luar, terutama unsur Cina. Hal itu tidak mengherankan, seperti halnya orkes gambang kromong, yang pada masa awal pertumbuhannya dibina dan dikembangkan oleh masyarakat keturunan Cina.

Menurut asal-usulnya, pada masa pemerintahan Belanda, di Bekasi dikenal adanya tuan-tuan tanah. Hampir 75\% wilayah Bekasi dikuasai oleh para tuan 
tanah, yang terdiri atas orang-orang Eropa dan Cina yang menguasai tanah tersebut, sedangkan rakyat Bekasi hanya sebagai penggarap tanah. Untuk mengawasi tanahtanah tersebut, tuan tanah mengangkat pembantu dekatnya yang disebut Potia, semua pekerja harus menuruti perintah potia. Potia juga menerima laporan dari mandor. Orang yang diangkat mandor adalah jagoan atau jawara yang ditakuti penduduk. Keberadaan tuan tanah tersebut semakin hari semakin menyengsarakan rakyat, sehingga muncullah Entong Tolo, seorang pembela rakyat yang dengan gigih melakukan perlawanan terhadap para tuan tanah. Kisah tentang pembela rakyat itulah yang sering dipentaskan dalam cerita lenong (Rosyadi et al., 2010: 35-36).

Kesenian Lenong dibedakan dalam dua jenis, yaitu : Pertama, lenong preman. yang mengetengahkan cerita sehari-hari yang ada di dalam masyarakat tersebut, seperti cerita tentang kesemena-menaan tuan tanah terhadap rakyat Bekasi. Kemudian muncul seorang jagoan yang bertindak sebagai pembela rakyat. Lenong preman ini juga sering dinamakan dengan Lenong Jago. Kedua, lenong denas. Dinamakan lenong denas karena para pemainnya menggunakan pakaian dinas. Lenong denas ini tidak sering dipentaskan (Rosyadi et al. 2010: 39-40).

Dalam perkembangannya, lenong merupakan generasi baru dari jenis kesenian wayang klitik. Pada tahun 1948 masyarakat Bekasi menyebutnya sebagai wayang dundung. Mengenai pergantian nama, tidak ada sumber yang dapat memastikan dan menjawab secara jelas mengapa terjadi pergantian nama. Namun secara material bentuk kesenian ini tidak mengalami perubahan, hanya pada penyebutan nama saja. Perubahan nama ini bergulir menjadi sandiwara lenong dan sekarang orang mengenalnya dengan nama lenong. (Sopandi et al., 2005: 86).

Kemudian pada tahun 1950-an terdapat satu grup lenong di Bekasi yang sangat terkenal, yaitu Kelompok Lenong Rindu Malam yang dipimpin oleh Bapak
Ombak. Pada waktu itu kesenian lenong merupakan kesenian yang cukup diminati oleh masyarakat di berbagai kalangan. Pertunjukan lenong biasanya dilaksanakan pada acara-acara syukuran khitanan, pernikahan atau acara syukuran panenan sawah atau berkebun. Di kalangan praktisi seni lenong, dikenal dua jenis lenong, yaitu lenong denes dan lenong preman. Cerita yang ditampilkan dalam lenong denes berkisar pada cerita raja, bangsawan dan pengawalnya. Pakaian yang dikenakan pemain lenong denes disesuaikan dengan peran yang dimainkannya, pemain yang menokohkan raja dan bangsawan mengenakan pakaian yang terbuat dari sutra. Ada juga masyarakat yang mengatakan lenong denes ini dengan nama wayang dungdung (Sopandi et al., 2005: 87-88).

Keberadaan kesenian lenong di Bekasi sekarang ini sudah hampir terlupakan oleh sebagian masyarakat. Bahkan, lenong di zaman sekarang merupakan kesenian yang langka. Hal ini terjadi mungkin karena beragamnya jenis hiburan yang menjadi pilihan masyarakat dan semakin berkurangnya generasi muda yang berminat untuk menekuni kesenian lenong ini. Bahkan dari generasi muda yang tadinya berprofesi sebagai pemain lenong sudah beralih profesi lain. Ada yang menjadi petani, pedagang, tukang ojeg atau menjadi buruh pabrik yang memberikan penghasilan (pendapatan) yang lebih baik dibandingkan sebagai pemain lenong.

Kesenian gambang kromong berasal dari nama dua buah alat perkusi, yaitu gambang dan kromong. Bilahan gambang sebanyak 18 buah biasanya terbuat dari kayu suangking, huru batu, atau kayu jenis lain yang merdu bunyinya bila dipukul. Adapun kromong yang berjumlah 10 buah (pencon) terbuat dari perunggu atau besi. Alat untuk meletakkan bilahan gambang dan kromong disebut ancak, berkaki cukup tinggi sehingga dapat dimainkan sambil berdiri atau duduk di kursi. Kedua alat musik ini terkadang tidak memakai kaki 
(ancak), sehingga pemainnya bisa sambil duduk bersila di atas lantai.

Kesenian ini perpaduan unsur budaya pribumi dan Cina. Secara fisik, unsur Cina tampak pada alat musik geseknya, yaitu tehyan, kongahyan, dan sukong. Adapun unsur pribuminya terdapat pada alat musik lainnya, yaitu gambang, kromong, gendang, kecrek, dan gong.

Selain itu, pada perbendaharaan lagu-lagu yang dibawakannya pun menunjukkan sifat-sifat pribumi dan Cina. Sifat pribuminya jelas terlihat dalam lagulagu seperti Jali-jali, Lenggang-lenggang Kangkung, Surilang, Balo-balo, Persi, Onde-onde, Ngunguk, Gelatik, dan sebagainya. Adapun lagu-lagu yang jelas bercorak Cina, baik nama, melodi, maupun liriknya seperti Citnosa, Cutaypen, Sipetmo, Macuntay, Sipatmo, Kong Jilok, dan sebagainya. Tak hanya itu, tangga nada yang digunakannya pun berasal dari bahasa Cina, yaitu syang atau hsyang, ceh atau tse, kong, oh atau ho, uh lio atau liu, dan suh (Rosyadi et.al.: 2010: 30-31)

Pada awalnya orkes gambang kromong hanya disukai kaum peranakan Cina, yaitu kaum Cina yang lahir di Indonesia. Istilah peranakan Cina ini ada di lingkungan penduduk Cina di Betawi, selain adanya istilah singkeh, yaitu mereka yang lahir di negeri leluhurnya, Negeri Cina.

Sekitar tahun 1880 atas usaha Tang Wangwe serta dukungan dari Bek (Wijkmeester) Pasar Senen, yaitu Teng Tjoe, orkes gambang dilengkapi peralatan musik setempat, seperti kromong, kempul, gendang, dan gong. Lagu-lagunya pun ditambah dengan lagu-lagu Sunda populer. Selanjutnya orkes gambang kemudian dikenal dengan nama orkes gambang kromong. Lagu-lagu-lagu Gambang Kromong Betawi yang terkenal, antara lain Jali-jali dan Kicir-kicir, sehingga kedua lagu tersebut sebagai lagu dalam atau lagu sayur. Dalam artian lagu-lagu tersebut selalu dinyanyikan orkes gambang kromong, selain lagu luar, yaitu lagu yang dinyanyikan atas permintaan para penonton (Rosyadi et al., 2010: 32-33).

Kesenian wayang kulit merupakan kesenian tradisional yang populer di daerah Bekasi. Pada masa lalu, hampir semua lapisan masyarakat terutama di pedesaan menggemari kesenian wayang kulit. Kesenian wayang kulit di Bekasi berasal dari daerah Cirebon yang mendapat pengaruh unsur budaya Jawa Tengah. Setelah menyebar ke wilayah Jawa Barat, maka kesenian wayang kulit ini memiliki karakteristik yang khas dan memiliki versi sendiri sesuai dengan kondisi daerahnya masing-masing. Oleh karena itu, ada versi Wayang Kulit Cirebon, Wayang Kulit Banten, dan Wayang Kulit versi Bekasi (Sopandi, 2009: 250).

Ciri-ciri yang tampak menonjol dalam kesenian Wayang Kulit Bekasi adalah: (1) Bahasa yang dipergunakan dalam pergelaran adalah dialek Bekasi, (2) Alat-alat yang digunakan sederhana dan mudah sekali untuk dibawa ke mana-mana, dan (3) komunikasi dengan para penonton erat sekali. Bentuk pergelaran merupakan teater terbuka yang mudah dilihat oleh para penonton (Sopandi, 2009: 251).

Kesenian Wayang Golek Bekasi pada umumnya sama dengan kesenian wayang kulit. Yang membedakannya adalah jenis wayang dan lakonnya saja. Wayang Golek Bekasi wayangnya terbuat dari kayu yang dibentuk seperti boneka, sedangkan wayang kulit wayangnya terbuat dari kulit binatang. Wayang Golek Bekasi sangat mirip dengan Wayang Golek Sunda. Cerita yang dibawakan oleh dalang merupakan cerita dari Wayang Golek Sunda. Lakon yang sering dipergelarkan antara lain cerita Nagasewu, Patalikrama, dan Babad Alas Amer.

Kesenian musik gambus adalah salah satu jenis musik yang cukup dikenal di kalangan masyarakat Bekasi. Musik ini banyak pula ditemukan pada masyarakat Betawi. Dimungkinkan munculnya musik gambus pada masyarakat Bekasi adalah karena bermigrasinya masyarakat di pinggiran Jakarta pada masa pendudukan 
Belanda ke arah timur (Bekasi sekarang). Kesenian musik gambus ini lebih mencirikan budaya Islam. Memang cukup beralasan bila dikatakan sangat bernuansa Islam, karena jenis musik ini berasal dari Timur Tengah (Tanah Arab).

Sementara itu, pengaruh Islam di Bekasi terjadi seiring dengan direbutnya benteng pertahanan Sunda Kelapa dari tangan Kerajaan Pajajaran oleh pasukan yang dipimpin oleh Pangeran Fatahilah, sekitar tahun 1527. Kemenangan pasukan Fatahilah membuka ruang bagi perkembangan agama Islam di Bekasi. Penyebaran agama Islam dilakukan oleh para pengikut Fatahillah yang berasal dari keturunan Sultan Abdul Fatah dari Banten. Karena itu, kehidupan agama memiliki pengaruh yang sangat kuat terhadap seluruh aspek kehidupan orang Bekasi (http://bloggerbekasi.com/ 2010/01/12/sejarah-panjang-bekasiii.

html). Oleh karena itu, sangat wajar musik gambus berkembang di wilayah Bekasi.

Kesenian ujungan merupakan seni permainan ketangkasan yang dilakukan oleh dua orang Jawara. Mereka saling memukulkan (menyabetkan) tongkat rotan ke arah kaki, sambil diiringi oleh tabuhan sampyong yang terdiri atas gambang dan totok (kentungan bambu). Di samping itu, terdapat dua orang bebeto (pemisah) yang bertugas melerai jika kedua jawara saling bergumul. Sementara penonton berkeliling membentuk kalangan (arena) dan sesekali bersorak riuh, bila ujung rotan mengena dan berhasil menjatuhkan lawan.

Seni permainan ujungan
mengandung 5 (lima) unsur utama, yaitu :

1) Hiburan dan kegemaran, permainan ini menimbulkan kesenangan bagi pemain maupun penontonnya.

2) Kecerdikan dan kewaspadaan. Permainan ini menuntut pemain harus cerdik dan waspada serta penuh konsentrasi.

3) Terampil dan cekatan. Permainan ini memerlukan kelincahan dalam memainkan rotan dan sebagaimana mendapatkan poin atau tidak berkurang poinnya.

4) Keberanian. Permainan ini dibutuhkan keberanian dan mental yang kuat supaya dalam pertarungannya tenang dan tidak gentar menghadapi lawan.

5) Ketabahan. Permainan ini melatih kesabaran, ketekunan, dan menahan emosi. Dengan sabar dan tawadhu (rendah hati) sehingga permainan ini akan berhasil (Sopandi, 2009: 254).

Pada masa penjajahan Belanda permainan ujungan dilarang keras (dikejarkejar oleh Marsouse Cap Garpuh: istilah orang Bekasi saat itu). Aparat Hindia Belanda ketika itu beranggapan bahwa permainan ujungan akan menjadi kuat dan berani sehingga akan menjadi ancaman laten bagi Belanda dan para tuan tanah ketika itu. Hal ini, telihat dari kegigihan masyarakat Bekasi dalam melakukan pergerakan bangsa melawan para tuan tanah dan aparat pemerintah HindiaBelanda. Sementara bagi para tokoh pergerakan permainan ujungan ini justru dijadikan unsur latihan bagi menempa kelima unsur di atas, sehingga tangguh dan mantap dalam berjuang. Di sisi lain, unsur magis dan kekebalan menjadi penunjang dalam permainan ini (Sopandi, 2009: 256257).

Selanjutnya, ada juga permainan anak-anak yang hampir sama dengan di daerah lain di Jawa Barat, di antaranya adalah: permainan gundu, gangsing, bola gebak, main dampu, congkak, balap karung, wawak gung, main karet, landar lundur, bakiak, jajangkungan (enggran), benteng, ketok pala babi, dan permainan das 16. Beraneka ragam permainan perlu adanya kajian yang lebih mendalam terutama dari segi nilai-nilai kebersamaan, ketangkasan, dan sebagainya.

\section{b. Sistem Penanggalan Masyarakat Bekasi}

Masyarakat Bekasi dulu erat sekali dengan sistem scoring atau memberi score (nilai) terhadap bulan-bulan dan hari-hari tertentu yang dipengaruhi oleh aktivitas 
kehidupan masyarakat pendukungnya. Sistem penanggalan tersebut mengandung persamaan bahwa dalam satu tahun terdiri atas 12 bulan yang disesuaikan dengan sistem penanggalan Islam dengan varian tertentu, seperti berikut:

Tabel 1. Sistem Penanggalan Islam

\begin{tabular}{|c|c|c|c|}
\hline No. & $\begin{array}{l}\text { Urutan } \\
\text { Bulan }\end{array}$ & $\begin{array}{l}\text { Nama Bulan } \\
\text { pada } \\
\text { Masyarakat } \\
\text { Bekasi } \\
\end{array}$ & $\begin{array}{c}\text { Nama Bulan } \\
\text { dalam } \\
\text { Kalender } \\
\text { Islam } \\
\end{array}$ \\
\hline 1. & $\begin{array}{l}\text { Bulan } \\
\text { Pertama }\end{array}$ & Sura & Muharam \\
\hline 2. & Bulan Kedua & Safar & $\begin{array}{l}\text { Sebutan } \\
\text { dalam Islam }\end{array}$ \\
\hline 3. & Bulan Ketiga & Mulud & $\begin{array}{l}\text { Maulud atau } \\
\text { Rabiul } \\
\text { Awwal }\end{array}$ \\
\hline 4. & $\begin{array}{l}\text { Bulan } \\
\text { Keempat }\end{array}$ & $\begin{array}{l}\text { Sili Mulud/Siri } \\
\text { Mulud }\end{array}$ & $\begin{array}{ll}\text { Seri } & \text { Mulud } \\
\text { atau } & \text { Rabiul } \\
\text { Akhir } & \\
\end{array}$ \\
\hline 5. & Bulan Kelima & Jumadil Awwal & $\begin{array}{l}\text { Sebutan } \\
\text { dalam Islam }\end{array}$ \\
\hline 6. & $\begin{array}{l}\text { Bulan } \\
\text { Keenam }\end{array}$ & Jumadil Akhir & $\begin{array}{l}\text { Sebutan } \\
\text { dalam Islam }\end{array}$ \\
\hline 7. & $\begin{array}{l}\text { Bulan } \\
\text { Ketujuh }\end{array}$ & Rejeb & Rajab \\
\hline 8. & $\begin{array}{l}\text { Bulan } \\
\text { Kedelapan }\end{array}$ & Ruwah/Rowah & Syaban \\
\hline 9. & $\begin{array}{l}\text { Bulan } \\
\text { Kesembilan }\end{array}$ & Puasa & Ramadhan \\
\hline 10. & $\begin{array}{l}\text { Bulan } \\
\text { Kesepuluh }\end{array}$ & Sawal & Syawwal \\
\hline 11. & $\begin{array}{l}\text { Bulan } \\
\text { Kesebelas }\end{array}$ & Apit & Zulqaidah \\
\hline 12 & $\begin{array}{l}\text { Bulan } \\
\text { Keduabelas }\end{array}$ & Haji/Aji & Zulhijjah \\
\hline
\end{tabular}

Sistem penanggalan dimaksud, sangat menentukan kegiatan masyarakat pendukungnya, misal dalam kegiatan hajatan, baik syukuran pernikahan, khitanan, dan sebagainya. Mereka sangat menghindari kegiatan-kegiatan tersebut dilakukan pada bulan Safar, Puasa, dan Apit. Penghindaran kegiatan pada bulan dimaksud karena di bulan tersebut terjadi perayaan-perayaan Islam. Seperti di bulan Sura, terdapat perayaan tanggal 1 Sura dan perayaan lebaran anak yatim. Kemudian, bulan Mulud terdapat perayaan Maulid Nabi Muhammad SAW. Sementara itu, pada bulan Apit yang diapit oleh dua bulan, yakni bulan Sawal dan bulan Haji. Bulan Sawal, terutama tanggal 1 Sawal terdapat perayaan besar Islam, yaitu Idul
Fitri, sedangkan pada bulan Puasa atau Ramadhan tidak sepatutnya melakukan kegiatan hajatan, karena bulan tersebut sedang dilangsungkan puasa bagi umat muslim (Sopandi, et.al., 2005: 33).

\section{c. U pacara Daur Hidup}

Ada beberapa jenis upacara daur hidup di kalangan masyarakat Bekasi. Dalam pandangan masyarakat Bekasi, setiap tahapan hidup yang dialami oleh setiap orang, semenjak dia lahir hingga wafat, merupakan tahap-tahap penting yang harus senantiasa disyukuri. Cara mensyukurinya adalah dengan mengadakan upacara atau selamatan yang biasanya tidak hanya melibatkan keluarga yang punya hajat saja, tetapi juga melibatkan kerabat dan para tetangga dekat. Tradisitradisi upacara ini banyak terkait dengan tradisi-tradisi dalam Islam, dan telah berlangsung secara turun-temurun.

Nuju bulan, artinya tujuh bulan, yaitu upacara yang dilakukan saat jabang bayi dalam kandungan berusia 7 bulan. Menurut pandangan masyarakat setempat, pada usia itu, bayi dalam kandungan sudah berbentuk sempurna dan sudah diberi roh oleh Allah. Itu sebabnya harus disyukuri dengan jalan mengadakan upacara syukuran.

Upacara nuju bulan dilakukan hanya untuk anak pertama, yang waktu pelaksanaannya biasanya antara tanggal 7 atau 17 bulan Hijriah. Upacara ini dilakukan dalam 3 tahap, yaitu selamatan tahlilan dengan membacakan Surat Yusuf dan pembacaan Rawi, mandi air kembang, dan ngirag atau gedog, yaitu mengurut tubuh ibu hamil yang dilakukan oleh dukun beranak. Maksudnya adalah untuk membetulkan posisi bayi dalam kandungan, agar bayi tidak lahir sungsang.

Ada beberapa sebutan untuk upacara ini di daerah Bekasi. Di kalangan orang Betawi, upacara ini disebut Akeke, sedangkan di kalangan orang Sunda upacara ini disebut Ekah atau Akekah. Upacara ini dilaksanakan pada saat bayi berusia $7-21$ hari. Upacara ini ditandai 
dengan pemotongan hewan kambing. Bila anak yang dilahirkan adalah anak laki-laki, maka kambing yang dipotong adalah 2 ekor, sedangkan bila anak perempuan, cukup 1 ekor (Rosyadi et al., 2010: 52).

Upacara Akekah biasanya dilaksanakan pada malam hari, sehabis shalat Isya, dengan mengundang tetangga dekat, dan dipimpin oleh seorang kyai atau ustadz. Inti dari upacara ini adalah membaca Tahlil dan pembacaan kitab Rawi, yang mengisahkan tentang kelahiran Nabi Muhammad SAW. Pada saat upacara ini pula, dilakukan pemotongan rambut bayi, dan pemberian nama.

Di kalangan orang Bekasi yang menganut agama Islam, anak laki-laki yang sudah memasuki akil balig harus segera dikhitan atau disunat, yaitu dibuang "kulup" atau kulit pada ujung penisnya. Di kalangan masyarakat Betawi di Bekasi, upacara khitanan pada umumnya dilakukan bila si anak sudah berumur 10 tahun ke atas, atau bila si anak sudah benar-benar menginginkannya. Bagi keluarga mampu, upacara khitanan biasa dirayakan dengan pesta atau hajatan dengan disertai hiburan. Khusus di kalangan orang Betawi, upacara sunatan/khitanan dengan pesta besarbesaran, dilaksanakan bila anak yang dikhitan adalah anak sulung.

Upacara sunatan biasanya dilakukan dalam 2 hari. Pada hari pertama, si anak dirias dengan mengenakan pakaian pengantin sunat. Pakaian pengantin sunat ini sama jenisnya dengan jenis baju kebesaran pengantin cara haji. Setelah didandani dengan pakaian pengantin sunat, ia dinaikkan di atas seekor kuda yang juga dirias. Selanjutnya pengantin sunat itu diarak berkeliling kampung. Iring-iringan terdiri atas: pengantin sunat yang menunggangi kuda rias, delman yang tumpangi oleh kedua orang tua pengantin sunat, diiringi dengan musik rebana ketimpring yang melantunkan Shalawat Badar, dan ondel-ondel. Pada hari kedua, dini hari si anak dibawa ke sungai untuk direndam, dengan maksud agar batang penis si anak menjadi kebal dan ketika dipotong tidak terlalu banyak mengeluarkan darah. Sekitar pukul 06.00 barulah anak itu disunat oleh bengkong, menggunakan peralatan yang sangat sederhana, yaitu sebilah pisau sunat dan dua batang bambu ukuran sumpit, yang disebut bambu pilit (Rosyadi et al., 2010: 54).

Selesai anak disunat, bagi keluarga yang mampu, selanjutnya mengadakan acara hiburan yang bisa berlangsung sampai 2-3 hari. Upacara ini sekarang sudah jarang dilakukan bahkan di kota Bekasi sudah tidak lagi melakukannya karena anak yang mau disunat cukup pergi ke dokter ahli khitan. Bagi keluarga yang mampu, upacara khitanan biasa dirayakan dengan pesta atau hajatan disertai hiburan yang dilakukan di gedung-gedung bahkan di hotel berbintang.

\section{d. Pengaruh Budaya Mataram, VOC dan Tuan Tanah}

Sejak kapan budaya Jawa atau budaya Mataraman muncul dalam masyarakat Bekasi? Apa bukti-bukti yang menguatkan adanya budaya Mataram terhadap kehidupan masyarakat Bekasi? Kedua pertanyaan itu tentu erat hubungannya dengan menguatnya VOC (Verenigde Oost-indische Compagnie), sebuah kongsi perdagangan Belanda, di wilayah Batavia.

Pada saat itu, tepatnya tanggal 10-13 Nopember 1610 terjadilah perjanjian antara Pangeran Wijayakrama dengan VOC yang diwakili oleh L. Hermit. Isi perjanjian antara lain: Pertama, orangorang Belanda yang datang ke Jayakarta akan diterima dengan baik oleh Pangeran Wijayakarta dan boleh berdagang; Kedua, VOC diperbolehkan mendirikan sebuah loji untuk menyimpan barang-barang dagangannya (Disparbud DKI Jakarta, 2003: 19-20). Perjanjian itu hanya tipu muslihat belaka untuk memperlancar maksud busuknya yaitu ingin menguasai Jayakarta dan ke depannya ingin menguasai daerah-daerah lain yang ada di wilayah Nusantara. 
Hal ini terbukti dalam pembuatan sebuah loji untuk menyimpanan barang dagangan mirip sebuah benteng pertahanan dan bahan-bahannya pun dari batu-batuan sehingga bangunan itu terlihat kokoh dan kuat. Melihat bangunan tersebut menyulut kemarahan Pangeran Wijayakarta terhadap VOC dan tidak sabar lagi ingin menghancurkan benteng tersebut. Pada tanggal 23 Desember 1618 Pangeran Jayakarta bersiap-siap untuk melakukan penyerangan secara besarbesaran terhadap VOC yang telah ingkar janji atau melanggar isi perjanjian yang telah disepakati itu (Disparbud DKI Jakarta, 2003: 21).

Dalam pertempuran itu Pangeran Wijayakarta menderita kekalahan dan mundur ke Banten. Pada tanggal 30 Mei 1619 Kota Jakarta jatuh ke tangan Kompeni Belanda (VOC) di bawah pimpinan Gubernur Jenderal Jan Pieterszoon Coen yang kemudian mengganti nama Jayakarta menjadi Batavia (sekarang Jakarta) (Disparbud DKI Jakarta, 2003: 22).

Dari Batavia, Kompeni Belanda (VOC) melakukan ekspansi dagang dan kekuasaan ke wilayah lain di Nusantara. Kondisi ini membuat marah Raja Mataram, Sultan Agung. Pada tahun 1628 sampai tahun 1630 Sultan Agung mengirimkan pasukan yang cukup banyak beserta perlengkapan perang dan bahan makanan ke Batavia untuk menghancurkan VOC. Sedangkan perbekalan dan peristirahatan pasukan ditempatkan di Bekasi, Karawang, Cirebon, dan Tegal. Namun sayang, pasukan Mataram gagal menguasai benteng Batavia bahkan menderita kekalahan. Perbekalan dan perlengkapan perang Mataram dihancurkan oleh pasukan Kompeni Belanda VOC (Lasmyati et al., 2010: 7-8).

Para prajurit yang selamat tidak berani kembali ke Mataram karena ada ultimatum dari Sultan Agung yang mengancam akan membunuh seluruh pasukan yang gagal melakukan penyerangan ke Batavia bila kembali ke
Mataram. Mereka lebih memilih menetap dan berkeluarga di sekitar Bekasi dan Karawang. Kaum urban dari Mataram ini tentu saja memberi tambahan warna kehidupan terhadap budaya masyarakat setempat, terutama di bidang kesenian, agama, dan sebagainya. Sebagai contoh kesenian topeng, ujungan, wayang kulit yang telah diuraikan di atas selalu mengklaim bahwa kesenian tersebut tumbuh sejak para pasukan Mataram menetap di Bekasi.

Di samping itu, ada juga nama tempat atau nama daerah yaitu Babelan. Ada dua versi cerita yaitu, pertama, merujuk pada seorang tuan tanah yang berasal dari etnis Cina, yang bernama Babe Lan. Kemudian tempat yang didiami oleh orang Cina tersebut dinamakan Babelan. Kedua, nama Babelan juga dapat ditemukan di daerah Karawang, Cirebon, Tegal, dan lain-lain. Daerah-daerah tersebut menjadi jalur distribusi pasukan Mataram. Nama Babelan adalah semacam base camp atau tempat istirahat pasukan Mataram. Tempat itu akhirnya dinamakan Babelan. (http://bloggerbekasi.com/2010 /01/12/sejarah-panjang-bekasi-ii.html).

Walaupun berhasil memukul mundur pasukan Mataram, kekuatan VOC di daerah pedalaman justru semakin lemah, karena sering diganggu oleh sisa pasukan Mataram dan Banten yang melakukan strategi perang gerilya. Untuk mempertahankan wilayahnya, VOC mendekati para tokoh dan jagoan (jawara) dengan memberikan hadiah berupa tanah atau menjualnya dengan harga yang sangat murah. Namun dalam praktik, penguasaan tanah lebih didominasi oleh orang Eropa dan etnis Cina. Sejak itu mulai dikenal istilah "tanah partikelir", di mana para tuan tanah memiliki kekuasaan mutlak atas tanah yang dikuasainya, bahkan memiliki kekuasaan seperti pemerintahan. Konon luasan tanah yang dikuasai pada waktu itu hampir sama dengan luas satu kecamatan atau beberapa desa di Kota Bekasi (Lasmiyati et al., 2010: 8). 


\section{PEN UTUP}

Dari paparan di atas bahwa Kota Bekasi sebelumnya merupakan sebuah kecamatan dari Kabupaten Bekasi. Pada Tahun 1996 statusnya ditingkatkan menjadi kotamadya dengan membawahi 8 kecamatan dan 50 kelurahan/desa. Sebelumnya, penduduk Kota Bekasi didominasi oleh suku Sunda. Oleh karena itu, budaya Sunda mewarnai kehidupan mereka sehari-hari seperti menggunakan bahasa Sunda sebagai bahasa pengantar, baik di dalam rumah maupun di lingkungan masyarakat. Seiring dengan perkembangan zaman yang begitu pesat sehingga proses migrasi penduduk di daerah ini cukup tinggi yang berdampak terhadap unsur-unsur budaya luar yang berkembang di daerah Bekasi. Bekasi yang menjadi kota urban, terkena imbas budaya luar seperti Betawi, Melayu, Jawa, dan lain-lain yang begitu mudah masuk dan memengaruhi nilai-nilai sosial budaya. Salah satunya adalah bahasa.

Kota Bekasi secara umum juga memiliki kekayaan budaya yang tidak kalah menariknya dengan kota/kabupaten lain yang ada di Jawa Barat, di antaranya kesenian tradisional yaitu: kesenian tari topeng, tanjidor, lenong, cokek, wayang kulit, wayang golek, ujungan, musik gambus, dan permainan anak-anak. Masyarakat Bekasi masih tetap melestarikan nilai-nilai budaya pening-galan para pendahulunya seperti sistem penanggalan dalam kegiatan hajatan seperti pernikahan. Tetapi tidak dipungkiri ada juga sebagian masyarakat telah meninggalkannya terutama mereka yang hidup di perkotaan.

Bekasi dipengaruhi juga oleh budaya dari Mataram. Hal ini dapat dipahami karena ketika pasukan Mataram akan menyerang Kota Batavia (sekarang DKI Jakarta), Bekasi dijadikan tempat penyimpanan perlengkapan perang termasuk bahan makanan. Begitu pula ketika pasukan Mataram mengalami kekalahan perang mereka yang selamat tidak berani kembali ke Mataram karena ada ultimatum dari Sultan Agung yang mengancam akan membunuh seluruh pasukan yang gagal melakukan penyerangan ke Batavia bila kembali ke Mataram. Mereka lebih memilih menetap dan berkeluarga di sekitar Bekasi dan Karawang. Kaum urban dari Mataram ini tentu saja memberi tambahan warna kehidupan terhadap budaya masyarakat setempat, terutama di bidang kesenian, agama, dan sebagainya. Sebagai contoh kesenian topeng, ujungan, wayang kulit yang telah diuraikan di atas selalu mengklaim bahwa kesenian tersebut tumbuh sejak para pasukan Mataram menetap di Bekasi.

\section{DAFTAR PUSTAKA}

\section{A. Buku}

Bappeda. 2013.

Kota Bekasi Dalam Angka, 2012, Bekasi: Badan Perencanaan Pembangunan Daerah Kota Bekasi dan Badan Pusat Statistik Kota Bekasi

Disparbud. 2003.

Jakarta Kota Juang. Jakarta: Dinas Kebudayaan dan Permuseuman Provinsi DKI Jakarta.

Kuntowijoyo. 1983/1984.

Beberapa Model Penulisan Sejarah, Depdikbud, Direktorat Jarahnitra. Jakarta: Proyek IDSN.

Koentjaraningrat. 1974. Kebudayaan, Mentalitas, dan Pembangunan. Jakarta: Gramedia.

Lasmiyati et al. 2010. Perekaman Peninggalan Sejarah Kota Bekasi, Departemen Kebudayaan dan Pariwisata. Bandung: Balai Pelestarian Sejarah dan Nilai Tardisional.

Lohanda, Mona et al. 1984. Sejarah Sosial DKI Jakarta, Depdikbud, Direktorat Jarahnitra. Jakarta: Proyek IDSN.

Mamar, Sulaiman et al. 1984/1985. Sejarah Sosial Daerah Sulawesi Tengah (Wajah Kota Donggala dan Pali). Depdikbud, Direktorat Jarahnitra, Jakarta: Proyek IDSN. 
Muhajir. 2000.

Bahasa Betawi: Sejarah dan

Perkembangannya (Rujukan Bahan

Muatan Lokal di Sekolah). Jakarta:

Yayasan Obor Indonesia.

Nurwati, Nunung et al. 2005.

Kajian Pola Penyusunan Penanganan dan Pengendalian Urbanisasi, Puslit Kependudukan dan Pengembangan SDM Lemit-UNPAD Bekerjasama dengan Pemerintah Provinsi Jawa Barat.

Pemda Kotamadya Bekasi. 1999.

Terbentuknya Kotamadya DT II Bekasi, Badan Perencanaan Daerah Kotapraja Bekasi.

Rosyadi et al. 2010.

$\begin{array}{llr}\text { Peta Budaya } & \text { Kabupaten } & \text { Bekasi, } \\ \text { Departemen } & \text { Kebudayaan } & \text { dan }\end{array}$

Pariwisata. Bandung: Balai Pelestarian Sejarah dan Nilai Tradisional.

Sopandi, Andi et.al. 2005.

Profil Budaya Masyarakat di Kota Bekasi, Dinas Pariwisata Pemuda dan Pemberdayaan Perempuan, Pemerintah Kota Bekasi.

Sopandi. 2009.

Sejarah dan Budaya Kota Bekasi, sebuah Catatan Perkembangan Sejarah dan Budaya Masyarakat Bekasi. Bekasi: Dinas Pemuda Olahraga, Kebudayaan, dan Kepariwisataan.

Suparman, Nana. 1985.

Mengenal Bekasi Kota Patriot. Bekasi: Rahman Press.

Tideman, J. 1983.

Tanah dan Penduduk Indonesia, Penduduk Kabupaten Batavia, Meester Cornelis, dan Buitenzorg. Terjemahan Hasan Basri. Jakarta: Bhratara.

\section{B. Internet}

http:id.wikipedia.org/wiki/Kota_Bekasi\#cite_N ote -23 di akses tanggal 24 Maret 2014 pukul 10.15 WIB).

http://asal-usul07.blogspot.com/2012 /01/asalusul-sejarah-kota-bekasi.html. di akses tanggal 1 April 2014 pukul 13.30 WIB).

http://www.bekasiurbancity.com/blog/2013/06/ 30/tari-topeng- peninggalan-senibudayabekasi/\#sthash.Flc5iNAf. dpuf, diakses tanggal 3 April 2014 pukul 10.10 WIB.

http://bloggerbekasi.com/2010/01/12/sejarahpanjang-bekasi-ii.html tanggal 4 April 2014 pukul 11.35 WIB).

http://www.bekasiurbancity.com/blog/2013/06/ 30/tari-topeng- peninggalan-senibudaya-bekasi/\#sthash.Flc5iNAf.dpuf diakses tanggal 7 April 2014 pukul 9.00 WIB.

http://www.facebook.com/Medirossa/posts/340 062739433887 diakses tanggal 3 April 2014 pukul 10.15 WIB.

http ://www. siidkotabekasi.com diakses tanggal 15 Maret 2014 pukul 14.15 WIB.

http://infoseputarkawasanmm2100.blogspot.co m/ diakses tanggal 1 April 2014 pukul 13.35 WIB). 